\title{
Implementation of Sanitation and Environmental Health As a Prevention of Tuberculosis Disease in Correctional Institute Class II B Mojokerto
}

\author{
Muhamad Hilmi Rahman Alauddin ${ }^{1^{*}}$ \\ ${ }^{1}$ Politeknik Ilmu Pemasyarakatan Badan Pengembangan Sumber Daya Manusia Hukum dan HAM \\ *Corresponding author, e-mail: putrotjondro17@gmail.com
}

Received 2020-03-20; Revised 2020-04-26; Accepted 2020-05-02; Published Online 2020-05-30

\section{Conflict of Interest Disclosures: \\ The authors declare that they have no significant competing financial, professional or personal interests that might have influenced the performance or presentation of the work described in this manuscript.}

\begin{abstract}
This study aims at describe the role of the health BPJS in implementing sanitation and environmental health programs in tuberculosis prevention in Class II B Penitentiary in Mojokerto. The research method was conducted by descriptive qualitative by presenting a detailed description of the state of the implementation of health services based on the facts available so that it can be interpreted to conclude the results of research based on data and facts that have been obtained. Data was collected through a structured interview method involving key informants in Class II B, Penitentiary Citizens Mojokerto, as many as four speakers. The results showed that the environmental health program in Class II B Penitentiary Citizens Mojokerto was still less than optimal and there was no specific program on preventing Tuberculosis in Class II B Penitentiary Citizens Mojokerto. The tuberculosis prevention program has been carried out using the PPI tuberculosis procedure, but the results have not been optimal because there are many facilitative and administrative shortcomings.
\end{abstract}

Keywords: Environmental health, tuberculosis prevention, PPI tuberculosis

\section{Introduction}

Environmental-based diseases are one of the biggest problems in Indonesia. According to Manalu (2010) argues that several factors affect health status, what is meant by some of these factors are inheritance factors, health service factors, behavioral factors, and environmental factors. And what affects the health 
status of individuals, families, groups, and communities is the environment that has the greatest influence and role (Noguera, 2003).

The Law of Republc Indonesia Number 36 of years 2009 concerning health, health definition is a healthy condition, physically, mentally, spiritually, and socially that allows everyone to live socially and economically. Akhmaddhian (2015) also notes thats the health development involves all aspects of community life and takes place in every individual, not least those who are undergoing criminal or detained in a Penitentiary and State Detention Center.

The correctional institution, hereinafter referred to as LAPAS, is a place to carry out the formation of prisoners and correctional students (Article 1 of Republic Indoensia Law Noumber 12 of years 1995). Prison fund prison inmates are also members of the community and have the same rights as other community members to achieve optimal health status. The treatment of health services for Penitentiaries can be used as one of the benchmarks of the success of development in the field of law both nationally and internationally because the Correctional Institution is a miniature of the community.

One of the factors that influence the achievement of the health status of Penitentiary Guided Communities is the state of sanitation and environmental health in Corrections Institutions (Gatherer, Jürgens \& Stöver, 2007). Sanitation and an unhealthy environment are the cause of the low level of physical and spiritual health which facilitates the spread of infectious diseases. Then the better the sanitary and environmental conditions, the higher the health level of the person. According to Purnawijayanti (2001) sanitation is a public health effort that emphasizes the supervision of various environmental factors that affect human degrees. Sanitation is an inseparable factor in the Prison environment. Termination of basic sanitation services will cause serious illnesses for prisoners (Fazel, \& Baillargeon, 2011; Marsland, et al, 2007). It can be recognized that the issue of prisons/remand center sanitation that has not yet met the standards becomes a separate issue in terms of care, which is the right of prisoners to get physical and spiritual care (Article 1 of Republic Indoensia Law Noumber 12 of years 1995) (Wowiling, 2017) Implementation of environmental health management carried out through efforts to improve health, safety, and control to meet environmental health quality standards and health requirements. These efforts are no exception for Lapas, LPKA, ROUTES, and ROUTAN Branches. In this problem, sanitation plays an important role in preventing infectious diseases (Akromuddin, 2013). Infectious diseases such as leptospirosis, scabies, and tuberculosis. The correctional facility for dangerous infectious diseases that are commonly found is tuberculosis (Tuberculosis) due to factors that support the spread of Tuberculosis such as sanitation, the environment, and the health of Prisoners. According to data from the Directorate General of Tuberculosis Correctional Services, it is included in the 3 most common diseases suffered by Correctional Prisoners (Fazel \& Baillargeon, 2011).

Tuberculosis is a common infectious disease, and in many cases is deadly (Kartasasmita, 2016). This disease is caused by various strains of mycobacteria, commonly Mycobacterium Tuberculosis (Allen, 1998; Van Crevel, et al., 2002). Tuberculosis usually attacks the lungs, but can also affect other body parts (Anggraini, et.al., 2018). Tuberculosis spreads through the air when someone with active tuberculosis infection coughs, sneezes, or spreads their saliva through the air (Werdhani, 2002). Tuberculosis infections are generally asymptomatic and latent. However, only one in ten cases of latent infection develop into active disease. If Tuberculosis is not treated then more than $50 \%$ of infected people can die. Based on the Indonesian Minister of Health Decree No.270 / Menkes / SK / 111/2007 concerning prevention and control of infections in hospitals and health care facilities. Prevention of tuberculosis is carried out by organizing the PPI (Infection Prevention Program) Tuberculosis program. In the PPI tuberculosis program there are 4 instruments, namely administration, managerial, environment, and PPE (Personal Protective Equipment). The instrument is a tuberculosis control and prevention program in general so that tuberculosis disease can be cut off in the community.

The implementation of tuberculosis control and prevention programs in prisons and remand centers needs to get our attention because of the dense conditions of occupancy in general in prisons and remand centers, health workers who have not been evenly distributed throughout prisons and remand centers, facilities and infrastructure, health services can further accelerate the transmission of tuberculosis infection to Penitentiary Residents. And in the PPI program, there are environmental programs that cover sanitation and environmental health, and in my opinion, sanitation is a major cause of transmission of tuberculosis. 


\section{Method}

This study uses a qualtitative research method also called artistic method, because the research process is artistic (less patterned), and is also referred to as an interpretive method because the research results are more pleasing to the interpretation of the data found in the field (Leavy, 2015). In this qualitative study explained about the prevention of Tuberculosis by using sanitation and environmental health factors in Class IIB LAPAS Mojokerto. This research was conducted at the Class II B Penitentiary in Mojokerto because Mojokerto Class IIB LAPAS was in the Mojokerto Regency which was one of the districts with the largest tuberculosis suspects in East Java and was ranked 5. The data gatherig by interview methode were involving officers and Class II B Penitentiary Citizens Mojokerto. With the following: (1) the head of Class II B prison in Mojokerto; (2) the head of Binadik Section of LAPAS Class II B Mojokerto; (3) the health Workers in tuberculosis disease prevention program in Class II B prison in Mojokerto; and (4) the person who suspected of tuberculosis suspension in Class II B prison in Mojokerto. The interview proses was conducted for 3 weeks starting on 12 of March s to 3 of April 2018 as data collection and research. The descriptive analysis uses to finding the meaning of the data results. The conclusion is making with focus to describing how the implementation of sanitation and environmental health programs in the prevention of tuberculosis in Class II B prison in Mojokerto. The study also uses the secondary data from polyclinic data, books, literature and documents as sources of information to increase understanding of the object of research for trianggualtion.

\section{Results and Discussion}

\section{A. The Information results from the respondents}

The first informant was the Head of the Penitentiary Class II B Mojokerto. He explained that the current Environmental sanitation and health the program could not be implemented optimally due to the lack of awareness of the Inmates and the Officers themselves. From the results of observations and interviews that have been conducted, researchers can draw conclusions from answers to questions given to informants about sanitation that to all Penitentiary Citizens and of course Correctional Officers themselves to be aware of the environment Prison.

Every Friday must always clean, especially the rooms and blocks. Every Friday clerk to check the state of the room. If it's not clean, they will immediately get punishment on the spot. And for Tuberculosis in the Mojokerto LAPAS, there is already assistance from the local health center. The obstacles in the sanitation program for the prevention of Tuberculosis are that environmental sanitation, especially ventilation is made in general and not in accordance with the PPI Tuberculosis guidelines. In Mojokerto Class IIB Laps itself ventilation is made the same as other Guided Residents' dwelling rooms so that the environmental sanitation program is not running optimally.

The second informant is the Head of the Guidance and Education Section. At the time of the interview, the informant was very cooperative and provided sufficient information for data searching. Based on the results of the interview, previously sanitation in the Mojokerto LAPAS was very poor, due to inappropriate land contours and also because it was under the river so that flooding often occurred. And for the residential room even now is pretty clean because every day a check is done when trolling the picket officers. The sanitation problem which is quite severe is a flood. For rooms, because overcrowded makes the air entering the room hot.

In the interview, the informant gave information that the prevention program could not run optimally because of the lack of awareness of the Fostered People themselves. Fostered residents do not care about environmental health, for example, smoking everywhere. And in the implementation for WBP who have contracted tuberculosis did not run optimally due to lack of supervision. In the following interview, the writer sought information about tuberculosis socialization conducted by health workers that tuberculosis socialization was held every 6 months and that it also collaborated with UPT PUSKESMAS (The public health center) Gedongan distric. So for socialization, we still hold it regularly but it must be monitored because so far it has not been effective.

The third informant is Class II B Penitentiary Health Officer Mojokerto. This Health Officer who deals directly with the Health and supervision of Penitentiary Guides. The initial health check-up starts from the 
Correctional Prisoners entered into LAPAS, and in a series of preliminary examinations conducted tuberculosis and HIV screening through form filling. And if a prisoner is infected or tuberculosis is indicated, it will be followed up. In handling tuberculosis cases sputum samples taken from WBP who suspect tuberculosis and if indicated positive, then we will move him into a special tuberculosis room and carry out tuberculosis healing programs such as administering drugs in collaboration with the Gedongan Public Health Center which has a laboratory and intensive spring in the program.

For environmental sanitation in the prevention of tuberculosis, the focus is more on ventilation. For ventilation in the clinic, there are two excuses and one AC (air conditioner), $2 \times 2$ meters of medicine room, and 1 bed. If you think there are $5 \times 7$ meters of this polyclinic. This air conditioner is exposed directly to Exhaouse so gusts of air from patients are not exposed directly to the officers. According to exhouse rules, it is below, but it is not possible to dismantle it besides the demand for health services, as well as the costs for changing or adding a space. And for the isolation room itself, like everything else, there is nothing special about ventilation.

We also got information about the cough ethics for Penitentiary Guided Residents, namely those who suspect or occupants of tuberculosis rooms, they interact normally and naturally. There is no ethical cough for them. In fact, smoking is common. Never been reprimanded and the answer is not smoking is not good.

The fourth informant was the Correctional Guidance Community who was infected with tuberculosis cases, on behalf of Suhidin from Mojokerto. The first time you entered Class IIB LAPAS, Mojokerto went straight to the clinic for a health check and admitted that you had tuberculosis. In the initial health check, WBP was immediately screened for tuberculosis and tuberculosis prevention and recovery program was carried out. Next, the researchers got a picture of the sanitation and health conditions in the Room of the Guided People. The lack of sanitation and health awareness for Foster Residents who suspect tuberculosis. In this case, it is necessary to hold strict supervision of them in fulfilling the right to health for the Prisoners. As stated by the informant, in the implementation of the tuberculosis disease prevention program in Class II B Prison, Mojokerto can run well. And consistently done.

\section{B. Sanitation and Environmental Health Program}

Based on Circular Letter PAS 373.PK.01.07.01 of 2016 concerning Sanitation and Environmental Health of LAPAS, LPKA, ROUTES, AND ROUTAN BRANCHES, LAPAS must pay attention to environmental aspects such as water, air, waste management, and others. In the water problem in LAPAS Class II B Mojokerto, inside LAPAS there is a problem with the drainage channel, where every rain the water channel will always overflow due to the contour of the land occupied by LAPAS Class II B Mojokerto under the river. Plus the drainage is clogged with garbage. As for drinking water, the Penitentiary Community gets two gallons of drinking water every two days in a room. Drinking water is obtained by refilling it in prison. The health standard for refill drinking water has been certified by the health department with water sources from Arjuno Mountain, Pacet, East Java.

\section{Meeting the needs of ventilation and air circulation}

In the application of environmental health standards, the room should not be allowed the existence of cigarette smoke, but according to the author's observation can be ascertained smoking activities in the room are still allowed. This will certainly have an impact on the Disease for Fostered Residents. According to the standard temperature inside the room is at least the same as the temperature of outdoor air. with occupant capacity that exceeds the limit, the temperature of the air in the room certainly becomes hot. Coupled with inadequate air ventilation.

1) Handling and management of waste and waste

In the application of waste management standards, include: (1) sorting, which separates organic and non-organic waste; (2) Collection, which is to provide a place of garbage in each residential room; (3) Garbage transportation, garbage transportation is carried out by collecting rubbish in each residential room every afternoon and collected into one in a cart, including kitchen and clinic. And gathered together in Temapat Rear Disposal; (4) Processing, the garbage that has been collected will be transported. In this case, LAPAS Class II B Mojokerto collaborates with the city government of Mojokerto in waste management. Collected into one. And processed by the city government. 


\section{2) Prevention of Tuberculosis}

According to the data obtained by the author, there are 3 people from Class II B correctional prison in Mojokerto who have been infected with the tuberculosis virus. Of the 2 people affected by TUBERCULOSIS, they had been infected with the TUBERCULOSIS virus from before he entered the Class II B prison in Mojokerto. And 1 person who was still in suspicion of TUBERCULOSIS was identified as having contracted the TUBERCULOSIS virus from inside the Class II B prison in Mojokerto.

In handling TUBERCULOSIS cases, LAPAS Class II B health staff Mojokerto conducts an initial screening of new prisoners who enter by filling out forms or asking directly to new prisoners. The author takes data directly, which shows the symptoms of illness suffered by residents of Class II B correctional prison in Mojokerto.

Table 1. The Clinical Data Mojokerto

\begin{tabular}{lc}
\hline Symptoms of Pain & Number of patients \\
\hline Itchy & 25 \\
Fever & 37 \\
ARI and Cough & 29 \\
Digestive Disorders & 31 \\
Etc & 20 \\
\hline Sources: LAPAS Class II B clinical data from Mojokerto in March 2018
\end{tabular}

From these data, it can be ascertained that the respiratory infection (respiratory tract infection) is classified as high which is complained by Class II B Prisoners in Mojokerto and is one of the symptoms of Tuberculosis. In the prevention and control of tuberculosis infections in prisons and remand centers several aspects must be met, namely:

\section{1) Managerial Pillar}

In the Managerial Pillar there is an effort to strengthen tuberculosis PPI, including the stipulation in writing: (1) the party responsible for PPI tuberculosis is the head of the prison and remand centers; (2) The structure of the tuberculosis PPI is adjusted to the tuberculosis DOTS team that has been formed, with the appointment of the PPI Lapas and ROUTAN coordinator; (3) The PPI tuberculosis activity plan is not only applied in polyclinics but also in blocks or residential rooms in the prison and remand centers.

In the application of these activities include: Screening for tuberculosis symptoms, WBP that will be free must have a health examination and get a health certificate, WBP affected by tuberculosis must be moved into a special room (isolation), place the suspects and tuberculosis patients in the waiting room not well ventilated, accelerate the process of cough handling to be expedited, WBP counseling about the ethics of coughing, sputum collection in tuberculosis patients is done in the open, providing maximum tuberculosis services, running an environmental control program, carrying out training and counseling tuberculosis PPI for health workers, conducting periodic checks on minimal staff Once a year for screening the possibility of tuberculosis cases.

In this case, according to the author, the managerial pillar of tuberculosis control and prevention in LAPAS class II B Mojokerto is not good, because, in LAPAS Class II B Mojokerto, the planned activities are only carried out modestly, for example, there is no mass screening of tuberculosis for all prisoners and $\mathrm{WBP}$, and the waiting room is not separated from patients who experience symptoms of cough and does not, provide diagnostic services quickly because the LAPAS Class II B Mojokerto clinic does not have a laboratory in tuberculosis diagnostic handling, and there are no examinations for LAPAS officers so it cannot be known whether the officer is infected or not.

\section{2) Pillar of Administrative Control}

This pillar is done to reduce the exposure of tuberculosis germs to officers, patients, visitors, and other WBP by reducing the presence of microbial splashes in the air. This risk cannot be eliminated $100 \%$ but can be significantly reduced by proper administrative efforts. These efforts include: (1) Carry out tuberculosis symptoms screening; (2) Carry out triage and separation of cough and non-cough cases; (3) Separation of 
blocks or rooms; (4) WBP and tuberculosis detainees were placed on the ground floor with ventilation following the PPI tuberculosis rules; (5) Implement cough ethics and provide IEC media; (6) Provide special care rooms with adequate ventilation for patients who have been diagnosed with tuberculosis to be isolated during the first 2 weeks of the intensive phase of positive WBP treatment infected with tuberculosis cases; (7) Prepare a clear system of reference, so that the service is more efficient and effective.

According to the observations of the authors, the administrative control pillars in Class II B LAPAS Mojokerto are currently only carried out such as screening using forms, separation of rooms between healthy WBP and tuberculosis positive WBP, and for diagnostic examinations of LAPAS Class II B Mojokerto have collaboration with Public Health Centre Gedongan due to incomplete health facilities and supported by the distance of health centers that are close to Class II B prison in Mojokerto. In its application, the least possible thing to do is to provide a special tuberculosis treatment room to be isolated during the first 2 weeks of the intensive phase of tuberculosis treatment because there are no more empty rooms due to the narrow land and the increasing number of WBP.

\section{3) Pillar of Environmental Control}

In the Pillar of tuberculosis environmental control is an effort to reduce the concentration of tuberculosis germs, so it does not transmit it to others. Efforts to control the environment can be done by prioritizing ventilation and air conditioning arrangements that lead to the concentration of tuberculosis germs in the open-air free of human traffic. In the ventilation used in prisons and remand centers, there are 3 types of ventilation, natural ventilation, mechanical ventilation, and mixed ventilation.

\section{Ventilating Penitentiary Room Citizens}

The Guided Residents Room in LAPAS Class II B Mojokerto consists of 2 floors. Which consists of upstairs 4 large rooms with a capacity of 25 people. WBP room ventilation only consists of vents with bars, measuring $60 \times 45 \mathrm{~cm}$. In large rooms, there are two vents, plus 1 large fan, while for small rooms, only consists of 1 ventilation. According to the authors, air ventilation in this large chamber is not very good in air circulators. The data is display in tabel 2.

Table 1. The Clinical Data Mojokerto

\begin{tabular}{ccccc}
\hline No & $\begin{array}{c}\text { Residential } \\
\text { Block Name }\end{array}$ & $\begin{array}{c}\text { Number of } \\
\text { Residential Blocks }\end{array}$ & $\begin{array}{c}\text { Occupancy Block } \\
\text { Area (M 2 ) }\end{array}$ & $\begin{array}{c}\text { NUMBER OF } \\
\text { WBP }\end{array}$ \\
\hline 1 & Inmate & 22 rooms & 537 & 312 \\
\hline 2 & Prisoner & 13 rooms & 409 & 130 \\
3 & Children & 2 rooms & 40 & 12 \\
4 & Woman & 2 rooms & 42 & 23 \\
\hline 5 & Cell & 4 rooms & 12 & 15 \\
6 & Insulation & 3 rooms & 18 & 10 \\
\hline
\end{tabular}

From these data, it can be seen that the area of the residential block with the number of WBP is not balanced and causes the temperature in the room to be very hot and there is no airflow in and out. When the writer entered the WBP room which was inhabited by around 55 people. The author feels very hot, and this is supported by the absence of sunlight on the 2nd floor because the building is high and the direction of sunlight is covered with trees and walls so that it can be considered humid. Coupled with smoking habits in the room that can lead to due to lack of awareness of the prisoners' health awareness. In the condition of these rooms can certainly be used as a good medium of transmission of the tuberculosis virus.

\section{E. Tuberculosis Special Isolation Room}

In the special tuberculosis isolation room, there were two noumber of tuberculosis infected patients and one other suspect tuberculosis with a room measuring 9 meters was inhabited with three people, with only one ventilation and no assistance in the means of airflow. The author tries to ask the head of Class II B LAPAS Mojokerto, in the addition of ventilation in the tuberculosis isolation room. For tuberculosis ventilation are all the same, in carrying out prevention it must indeed be controlled from all parties, ventilation cannot be changed apart from historical buildings so this will affect the upper floor. 
So the addition of ventilation in the isolation room cannot be run. Coupled with the behavior of WBP suspect tuberculosis who is still openly smoking, because it can aggravate the pain. And for the reception of sunlight itself can be received in the special tuberculosis room, namely in the morning until noon. Because the isolation rooms face east.

\section{F. Ventilation in LAPAS Class II B Polyclinic Mojokerto}

LAPAS Class II B Polyclinic Mojokerto is housed in a room measuring about $6 \times 6$ meters. Inside the polyclinic itself, there is one AC (air conditioners) and two window fans. The window fan itself is placed above the ventilation, and the air conditioner is placed opposite the ventilation wall and chairs and tables for consultation or medical treatment the patient is in the middle of the center and leads to the opposite. So for health workers themselves when dealing directly with patients, the exposure is not directed to the health workers, but directly inhaled by exhouse who are in the air vents.

According to the authors, the space used in the polyclinic is very improper due to the narrow examination room with one bed and mixed with a file. And the medicines themselves are put in a warehouse. And in air ventilation, the clinic has one air vent that has been installed with exhaust and assisted with air conditioning. Coupled with the absence of triage between a cough and other symptom patients so that all patients mixed while waiting for the examination turn. In this case, the LAPAS Class II $\mathrm{B}$ clinic in Mojokerto could become a place for the spread of the tuberculosis virus if there were no specific actions.

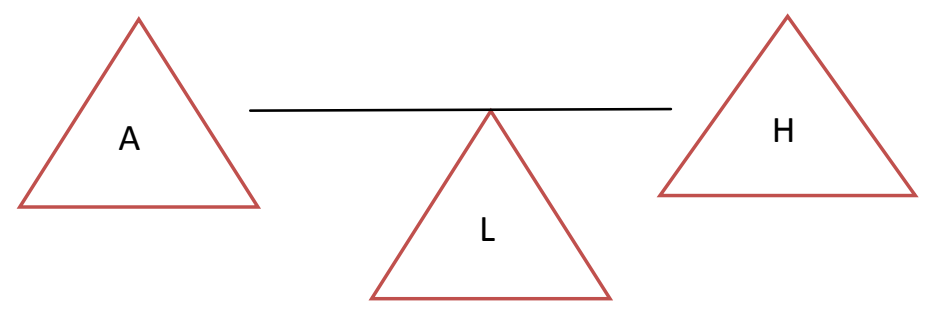

Fig. 1 Gordon Triangle

Gordon's theory as display in Fig. 1 also called triangle Gordon environmental epidemiology (Wallace, Pellizzari, \& Gordon, 1993) explained that agents, hosts and the environment must be balanced. And the authors, in this case, show the epidemiology of tuberculosis cases in Class II B prison in Mojokerto.

$$
\begin{aligned}
& \mathrm{A}=\text { Agent } \\
& \mathrm{H}=\text { Host } \\
& \mathrm{L}=\text { Environment }
\end{aligned}
$$

The agent means the Mycobacterium Tuberculosis germ. From the research, tuberculosis germs can die if exposed to sun exposure and can live dormant if in a humid place. The host of this tuberculosis germ case is a human or WBP, Health Officer and Class II B prisoner Mojokerto himself. Many factors can affect the host, many factors affect the host, including knowledge, education, and immunity. The residents of LAPAS Class II B Penitentiary in Mojokerto are expected to get maximum knowledge about tuberculosis to avoid the disease. The environment in the distribution of tuberculosis germs is primarily air, therefore every LAPAS especially the WBP rooms, isolation rooms, and polyclinics must get good airflow or ventilation. If these three components are not good then intervention will be carried out on the three, and according to the writer at Class II B prison in Mojokerto, the worst is environmental problems, such as air. Due to various problems, such as funding or building patterns, it cannot be maximally implemented in preventing tuberculosis cases.

\section{G. Pillar of Personal Protective Equipment}

It is an effort to protect prison and detention officers who work in environments with micro contamination (tuberculosis germs) that cannot be eliminated by administrative and environmental efforts. In the rules in the tuberculosis PPI guidebook, LAPAS officers who make direct contact must use particulate respirators to avoid transmission, and tuberculosis patients only need to use surgical masks. 
According to the author's observations, the authors considered that the pillars of personal protective equipment in LAPAS Class II B Mojokerto could not be carried out optimally because during direct contact with WBP suspect tuberculosis LAPAS officers did not use masks or others. Whereas tuberculosisinfected WBPs when in contact with other WBPs do not use masks or any tools so the risk of transmission is quite large.

\section{Conclusion}

The results of this study indicate the low quality of health care in prison facilities, which do not support the handling of cases of tuberculosis in detention centers. Based on existing regulations, detention centers must meet standards and pay attention to environmental aspects such as water, air, waste management, etc. In the application of environmental health standards, the room should not be allowed the existence of cigarette smoke, but in fact smoking in the room is still allowed. In handling tuberculosis cases, health staff in Class II B Mojokerto detention centers screen the incoming new prisoners by filling in forms or inquiring directly with new inmates. From this data, it can be ascertained that respiratory infections (respiratory infections) are classified as high complained of by Class B prisoners in Mojokerto and are one of the symptoms of tuberculosis in the prevention and control of tuberculosis infections in prisons and detention centers. The results of this study indicate that several aspects of health care must be fulfilled immediately, namely: the managerial pillar, the administrative control pillar and the environmental control pillar.

\section{References}

Akromuddin, W. (2013). Pengaruh Perilaku Sehat, Sanitasi Rumah Dan Status Sosial Ekonomi Terhadap Kejadian Penyakit Tubercolosis (TUBERCULOSISC) Di Kecamatan Mojowarno. Swara Bhumi, 2(1), 222-231.

Allen, B. W. (1998). Mycobacteria. In Mycobacteria protocols (pp. 15-30). Humana Press.

Anggraini, D. I., Kristin, D. I., \& Dwiprahasto, I. (2018). The influence of acetylation status of tuberculosis patients on the isoniazid serum concentrations and sputum conversion after intensive phase therapy. J Med Sci, 50(1), 59-69.

Fazel, S., \& Baillargeon, J. (2011). The health of prisoners. The Lancet, 377(9769), 956-965.

Kartasasmita, C. B. (2016). Epidemiologi tuberkulosis. Sari Pediatri, 11(2), 124-9.

Leavy, P. (2015). Method meets art: Arts-based research practice. Guilford Publications.

Manalu, H. S. P. (2010). Faktor-faktor yang mempengaruhi kejadian TUBERCULOSIS paru dan upaya penanggulangannya. Jurnal Ekologi Kesehatan, 9 (4 Des).

Noguera, P. A. (2003). The trouble with Black boys: The role and influence of environmental and cultural factors on the academic performance of African American males. Urban education, 38(4), 431-459

Akhmaddhian, S. (2015). Analisis Pertanggungjawaban Tenaga Medis yang melakukan Tindak Pidana Malpraktek menurut UU Nomor 36 Tahun 2009 Tentang Kesehatan. UNIFIKASI: Jurnal Ilmu Hukum, 1(1).

Republic Indonesia (2009). Undang-undang Republik Indonesia nomor 36 tahun 2009 tentang Kesehatan. Jakarta Republik Indones.

Marsland, B. J., Nembrini, C., Grün, K., Reissmann, R., Kurrer, M., Leipner, C., \& Kopf, M. (2007). TLR ligands act directly upon $\mathrm{T}$ cells to restore proliferation in the absence of protein kinase $\mathrm{C}-\theta$ signaling and promote autoimmune myocarditis. The Journal of Immunology, 178(6), 3466-3473.

Purnawijayanti, H. A. (2001). Sanitasi Higiene \& Gatherer, A., Jürgens, R., \& Stöver, H. (2007). Health in prisons: a WHO guide to the essentials in prison health. WHO Regional Office Europe.

Republic Indonesia (1995). Undang-undang Republik Indonesia nomor 12 tahun 1995 tentang Pemasyarakatan. Jakarta Republik Indonesia.

Republic Indonesia (1995). Undang-undang Republik Indonesia nomor 12 tahun 1995 tentang Pemasyarakatan. Jakarta Republik Indonesia. 
Van Crevel, R., Ottenhoff, T. H., \& Van Der Meer, J. W. (2002). Innate immunity to Mycobacterium tuberculosis. Clinical microbiology reviews, 15(2), 294-309.

Wallace, L. A., Pellizzari, E. D., \& Gordon, S. (1993). A linear model relating breath concentrations to environmental exposures: application to a chamber study of four volunteers exposed to volatile organic chemicals. J Expo Anal Environ Epidemiol, 3(1), 75-102.

Werdhani, R. A. (2002). Patofisiologi, diagnosis, dan klafisikasi tuberkulosis. Jakarta: Departemen Ilmu Kedokteran Komunitas, Okupasi, dan Keluarga. FKUI. Hal, 2-3.

Wowiling, F. F. (2017). Pemenuhan Hak Narapidana Lapas Kelas Iia Manado Berdasarkan Pasal $14 \mathrm{Uu}$ No. 12 Tahun 1995 Ditinjau Dari Perspektif Ham. LEX PRIVATUM, 5(4).

Article Information (Supplementary)

Copyrights Holder: $<$ Alauddin $><2020>$

\section{Conflict of Interest Disclosures:}

The authors declare that they have no significant competing financial, professional or personal interests that might have influenced the performance or presentation of the work described in this manuscript.

$\begin{array}{ll}\text { Counseling } & \end{array}$

http://dx.doi.org/10.23887/bisma.v3i1

First Publication Right: BISMA The Journal of Counseling

Open Access Article I CC-BY Creative Commons Attribution 4.0 International License.

Word Count: $\mathbf{5 1 8 0}$ 